\title{
Eribulin Regimen
}

National Cancer Institute

\section{Source}

National Cancer Institute. Eribulin Regimen. NCI Thesaurus. Code C160030.

A chemotherapy regimen consisting of eribulin that may be used in the treatment of advanced breast cancer; and soft tissue and uterine sarcomas. 